\title{
Response of Aspirin-allergic Patients to Challenge by Some Analgesics in Common Use
}

\author{
A. P. SMITH
}

British Medical fournal, 1971, 2, 494-490

\section{Summary}

Challenge tests with some analgesics in common use were performed in five aspirin-sensitive asthmatics. Marked falls in FEV 1 were observed after ingestion of paracetamol, indomethacin, mefenamic acid, and dextropropoxyphene in some subjects. The mechanisms of analgesic-induced asthma are discussed: it is believed to be a non-immunological process of great practical importance when prescribing analgesics to asthmatics.

\section{Introduction}

Symptoms of asthma, chronic rhinitis, urticaria, and angioncurotic oedema may occur in patients who arc allergic to aspirin (Van Leeuwen, 1924; Bruce Pearson, 1963; Samter and Becrs, 1968). These symptoms rarely occur in the same patient, and more usually asthma, rhinitis, and urticaria are seen scparately. Classically, the syndrome first presents in the third or fourth decade of life with watery nasal discharge, and later with nasal polypi. After a variable interval from weeks to years, bronchial asthma is first noticed, often being precipitated by nasal polypectomy or by aspirin ingestion. Thereafter the patient experiences persistent wheezing with severe, even life-thrcatening, attacks of asthma after taking aspirin. Avoiding aspirin, however, does not abolish the asthma, which is usually well controlled by small regular doses of corticosteroids.

In addition to aspirin, other drugs or chemicals may precipitate attacks of asthma in patients who suffer from this condition. These include alcohol, indomethacin, amidopyrine, and tartrazine (Samter and Beers, 1968), the latter being a ycllow colouring material commonly found in soft drinks, canned vegetables, and many other foodstuffs.

This paper presents the results of air-flow measurements on five aspirin-sensitive patients challenged by some other commonly used analgesics. Samter and Beers (1968) challenged aspirin-sensitive patients with a number of salicylic acid esters, thioaspirin, and paracetamol, but recorded no untoward effects. They did not, however, include any specific measurement of bronchial constriction.

\section{Patients and Method}

Dctails of the case historics of the firc patients are presented in Table I. Two were admitted specifically for the tests, two were admitted with status asthmaticus and subsequently investigated, and in one all tests were performed as an outpatient. The nature of the tests was explained to the patients. One (Case 2)

TABLE 1-Details from the Case Histories of the P'atients Investigated

\begin{tabular}{|c|c|c|c|c|c|}
\hline & Case 1 & Case 2 & Case 3 & Case 4 & Case 5 \\
\hline 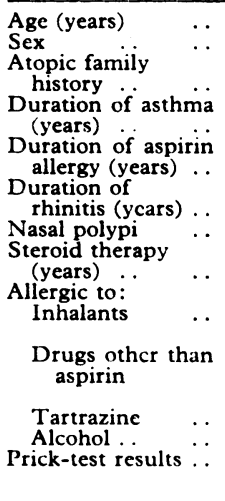 & $\begin{array}{c}10 \\
10 \\
15 \\
\text { Present } \\
1 \\
0 \\
\text { Para- } \\
\text { cetamol } \\
\text { Yes } \\
\text { Yes } \\
\text { Eggs. } \\
\text { Milk }\end{array}$ & $\begin{array}{c}48 \\
\text { F. } \\
\text { Present } \\
4 \\
4 \\
8 \\
\text { Present } \\
1 \\
0 \\
\text { Paracetamol. } \\
\text { Indomethacin. } \\
\text { Penicillin } \\
\text { Yes } \\
\text { Yes } \\
0\end{array}$ & $\begin{array}{c}\text { Pollen. } \\
\text { IHouscdust } \\
0 \\
\\
0 \\
0 \\
\text { Grass pollen. } \\
\text { House mitcs }\end{array}$ & $\begin{array}{c}51 \\
M . \\
0 \\
3 \text { months } \\
3 \text { months } \\
0 \\
0 \\
0\end{array}$ & $\begin{array}{c}0 \\
0 \\
\\
\\
0 \\
0 \\
\text { Tree } \\
\text { pollen }\end{array}$ \\
\hline
\end{tabular}

had a history of recurrent backache treated with indomethacin associated with severe asthmatic symptoms, and ultimately status asthmaticus. Another (Case 1) had noticed exacerbations of her wheeze and chronic rhinitis after the use of paracetamol. All the patients had a clear history of asthma attacks after taking aspirin.

The patients were challenged by the following drugs in no set order: paracetamol $500 \mathrm{mg}$, mefenamic acid $250 \mathrm{mg}$, indomethacin $25 \mathrm{mg}$, dextropropoxyphene $65 \mathrm{mg}$, phenylbutazone $100 \mathrm{mg}$, and inert white lactose tablets. Aspirin itself was not used because a cautious pilot study in one patient had shown it might be dangerous. The tests were performed under the same circumstances in each patient, and in all cases smoking and the consumption of soft drinks, tea, or coffee was forbidden, and so was the use of a bronchodilator drug for 12 hours before the test. The forced expiratory volume in onc sccond $\left(\mathrm{FEV}_{1}\right)$ was measured every 30 minutes on a dry bellows type spirometer (Vitalograph), the maximum of three consecutive readings being recorded. Any uncomfortable wheezing was relieved by inhaling $0.5^{\circ}{ }_{0}$ isoprenaline from a Wright's nebulizer flowing at 8 litres/min and the test was terminated. 

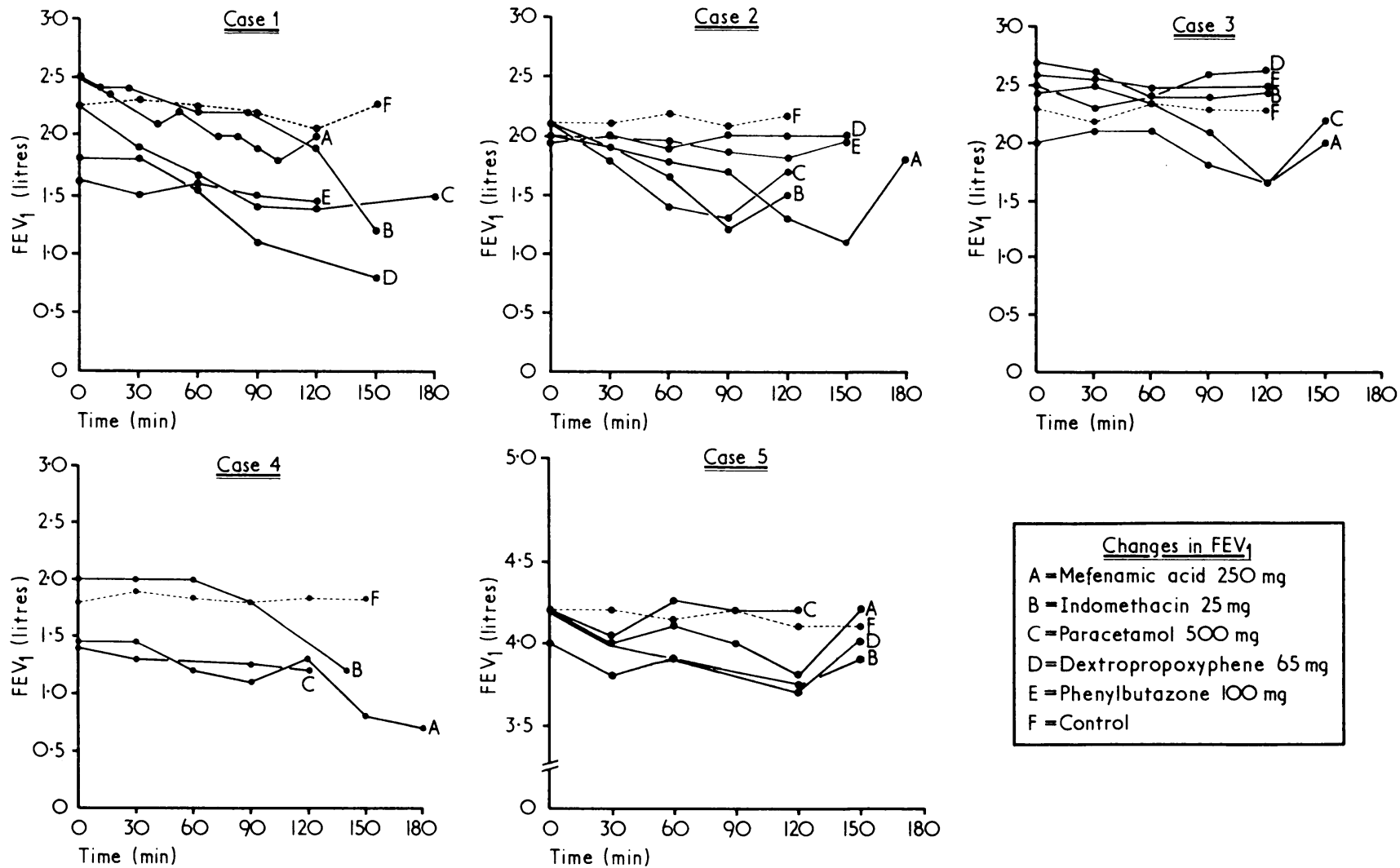

Changes in FEV
$A=$ Mefenamic acid $250 \mathrm{mg}$
$B=$ Indomethacin $25 \mathrm{mg}$
$C=$ Paracetamol $500 \mathrm{mg}$
$D=$ Dextropropoxyphene $65 \mathrm{mg}$
$E=$ Phenylbutazone $100 \mathrm{mg}$
$F=$ Control

\section{Results}

The changes in $\mathrm{FEV}_{1}$ are presented in the Chart and the percentage maximum changes in $\mathrm{FEV}_{1}$ for each drug in Table II. In no patient did the control preparation cause a change in $F E V_{1}$ of more than $10^{\%} \%$, nor was rhinitis or wheezing induced.

The association of rhinitis with each analgesic challenge is presented in Table III. This symptom was seen after challenge with paracetamol, indomethacin, and mefenamic acid; no patient complained of rhinitis after dextropropoxyphene or phenylbutazone. It will be noted that the most severe wheeze and the most severe rhinitis were not always seen together in the same patient; indeed, the patient with the most severe rhinitis (Case 5) had the least $\mathrm{FEV}_{1}$ response to all the drugs. Similarly, a drug causing rhinitis in one patient would be associated with wheezing in another.

TABLE II-Percentage Maximum Fall in FEV ${ }_{1}$ after Challenge by Each Drug

\begin{tabular}{|c|c|c|c|c|c|}
\hline Drug & Case 1 & Case 2 & Case 3 & Case 4 & Case 5 \\
\hline $\begin{array}{l}\text { Paracetamol } \\
\text { Indomethacin } \\
\text { Mefenamic acid } \\
\text { Dextropropoxyphene } \\
\text { Phenylbutazone }\end{array}$ & $\begin{array}{r}37 \cdot 7 \\
52 \cdot 0 \\
28 \cdot 0 \\
55 \cdot 5 \\
9 \cdot 4\end{array}$ & $\begin{array}{r}38 \cdot 0 \\
42 \cdot 0 \\
45 \cdot 0 \\
5 \cdot 0 \\
10 \cdot 0\end{array}$ & $\begin{array}{r}32.6 \\
8.0 \\
17.5 \\
9.4 \\
5.7\end{array}$ & $\begin{array}{r}14 \cdot 2 \\
40 \cdot 0 \\
51 \cdot 7 \\
=\end{array}$ & $\begin{array}{l}5 \cdot 0 \\
9 \cdot 5 \\
9 \cdot 5 \\
9 \cdot 75 \\
-\end{array}$ \\
\hline Control & 6 & $4 \cdot 7$ & $4 \cdot 3$ & 0 & 2.5 \\
\hline
\end{tabular}

TABLE III-Association of Rhinitis with Challenge by Each Drug

\begin{tabular}{|c|c|c|c|c|c|}
\hline Drug & Case 1 & Case 2 & Case 3 & Case 4 & Case 5 \\
\hline $\begin{array}{lc}\begin{array}{l}\text { Paracetamol } \\
\text { Indomethacin }\end{array} & \ldots \\
\text { Mefenamic acid } & \ldots \\
\text { Dextropropoxyphene } \\
\begin{array}{l}\text { Phenylbutazone } \\
\text { Phe }\end{array}\end{array}$ & $\begin{array}{c}++ \\
+++ \\
0 \\
0 \\
0\end{array}$ & $\begin{array}{c}0 \\
+++ \\
0 \\
0 \\
0\end{array}$ & $\begin{array}{c}0 \\
++++ \\
+++ \\
0 \\
0 \\
0\end{array}$ & $\begin{array}{c}++++ \\
0 \\
++ \\
=\end{array}$ & $\begin{array}{c}++ \\
+++ \\
+++ \\
0 \\
0\end{array}$ \\
\hline $\begin{array}{ll}\text { Control } \quad \ldots \\
\end{array}$ & 0 & 0 & 0 & 0 & 0 \\
\hline
\end{tabular}

+++ Severe rhinitis lasting for several hours.

++ Rhinitis lasting for less than two hours after challenge.

++ Mild rhinitis lasting for about half an hour during the test.
Uncomfortable wheczing was rapidly relicved in all cascs by isoprenaline. Delayed reactions were not seen. Rhinitis, on the other hand, often persisted.

\section{Discussion}

We have shown that considerable changes in $\mathrm{FEV}_{1}$, accompanied in some cases by asthma and rhinitis, may occur when aspirinallergic subjects are challenged by analgesic drugs other than aspirin. Paracetamol, indomethacin, and mefenamic acid were found to cause the most severe and frequent reactions; dextropropoxyphene caused a severe reaction in one patient (Case 1), but phenylbutazone did not have any untoward effects in any of the patients tested (Cases 1-3). The association of indomethacin with attacks of wheezing in aspirin-allergic subjects has been described by Vaneslow and Smith (1967) and Samter and Beers (1968). Paracetamol, mefenamic acid, and dextropropoxyphene, however, have not been regarded as harmful to these patients in the past. It is of interest to note at this point that Brocks (1967) found bronchoconstriction in patients with osteoarthritis treated with flufenamic acid, a drug closely related to mefenamic acid.

From the results of this investigation there seems to be considerable individual variation in the response of this group of patients to challenge by different analgesics; thus a patient who consistently reacted unfavourably to indomethacin might have little or no reaction to mefenamic acid, and in another the reverse might be true. Similarly, a drug would produce rhinitis in one individual and asthma in another. The reason for these inconsistencies is by no means clear. Furthermore, the mechanism of analgesic allergy remains unexplained.

Paradoxically, analgesics have often been reported as being beneficial in bronchial asthma, though they have never become a well-accepted method of treatment. Aspirin (Bruce Pearson, 1963), amidopyrine and phenazone (Herxheimer and Stresemann, 1961), phenylbutazone (Von Rechenberg, 1962), and mefenamic acid (Jackson, Raymer, and Etter, 1968) are reported 
to be of value in the treatment of asthma. Collier et al. (Collier and Shorley, 1960, 1963; Collier, James, and Schneider, 1966; Collier, James, and Piper, 1968) produced laboratory evidence which tends to confirm these long-held clinical observations. They have shown that the bronchoconstriction caused by bradykinin prostaglandin $F 2 \alpha$, adenosine triphosphate, and slow reacting substance in anaphylaxis (SRS-A), but not by histamine, in pithed guinea-pigs and isolated muscle strips is inhibited by aspirin and other analgesics, such as indomethacin and mefenamic acid. Furthermore, aspirin injected subcutaneously blocks the flare (axon reflex) of the triple reaction caused by bradykinin injection. This and the observations of Collier et al. would suggest that the protection afforded by aspirin in blocking kinin-induced bronchoconstriction is due to inhibition of local bronchial reflex arcs.

Samter and Beers (1967), in their extensive review of this subject, suggested that the cause of aspirin allergy lies in an alteration of bronchial and nasal nociceptors. Their hypothesis suggests that normal receptors, normally protected from kinin stimulation by aspirin, are so altered by a pre-existing disease process that they are stimulated rather than protected by aspirin. This concept rests on the assumption that the theory advanced by Paton $(1961,1967)$ to explain the action of acetylcholine and adrenergic antagonists applies to kinins and aspirin. This theory supposes that factors which act as agonists come into contact with, and dissociate rapidly from, receptor sites, and that antagonists form a stable complex with the receptor site, thus preventing access by agonists. A suggestion is that the receptor sites are changed in such a way that they are unable to bind aspirin and then this drug may act in the same way as the kinins it normally antagonizes-that is, as an agonist. If this is the case then other chemicals which act in a similar manner to aspirin and affect the same receptor sites should result in comparable reactions.

We have shown that, in the patients tested, this is true for paracetamol, mefenamic acid, indomethacin, and dextropropoxyphene but not for phenylbutazone, though it.is possible that this would be found to cause bronchoconstriction if more patients were tested. We submit this as evidence in support of the hypothesis proposed by Samter and Beers (1967), but are unable to offer any explanation for the change in receptor site characteristics, except to suggest that it is part of the same pathological process that causes the nasal polypi and the chronic rhinitis that are almost invariably associated with the syndrome.

Though this explanation may seem unsatisfactory, it forms a basis for further study. Other explanations of aspirin allergy have been based on immunological theory, but investigations into the immunology of the disease have largely proved unsuccessful. Attempts to demonstrate antibodies to aspirin and other salicylates in humans by using passive cutaneous anaphylaxis, micro-precipitation tests, passive haemagglutination tests, and lymphocyte transformation tests have been negative (Giraldo, Blumenthal, and Spink, 1969; Girard, Hildebrant, and Favre, 1969). Giraldo et al. review the literature and conclude that there is no satisfactory evidence that immunological factors are involved in aspirin allergy. The wide variation in molecular structure of the drugs which produce a similar reaction tends to reinforce this view. Indeed, we recommend that the term "aspirin allergy" be abandoned altogether in this context, and a term such as "analgesic-induced asthma syndrome" be substituted until the cause of the disease is understood.

In terms of practical medicine this investigation underlines the importance of great caution in prescribing analgesic drugs to patients thought to be sensitive to aspirin. Exacerbations of asthma or an increase in steroid requirement in patients with a painful condition requiring analgesics should be evaluated in the light of the knowledge that such drugs may cause severe bronchoconstriction. In cases of doubt it is justifiable to perform cautious analgesic challenge tests, though this procedure is not recommended in the case of aspirin itself as challenge with even minute doses of this drug may result in a life-threatening reaction; this is not likely to happen with other analgesics.

\section{References}

Brocks, B. E. (1967). Annals of Physical Medicine, 9, Suppl. p. 114. Collier, H. O. J., and Shorley, C. (1960). British Fournal of Pharmacology and Chemotherapy, 15, 601 .

Collier, H. O. J., and Shorley, C. (1963). British fournal of Pharmacology and Chemotherapy, 20, 345 .

Collier, H. O. J., James, G. W. L., and Schneider, C. (1966). Nature, 212 411.

Collier, H. O. J., James, G. W. L., and Piper, P. J. (1968). British fournal of Pharmacology, 34, 76 .

Girard, J. P., Hildebrant, F., and Favre, H. (1969). Helvetica Medica Acta, $35,86$.

Giraldo, B., Blumenthal, M. N., and Spink, W. W. (1969). Annals of Intcrnal Medicine, 3, 479.

Herxheimer, H., and Stresemann, E. (1961). Nature, 192, 1089.

Jackson, R. H., Raymer, W. J., and Etter, R. L. (1968). Journal of the Kansas Medical Society, 4, 474.

Paton, W. D. M. (1961). Proceedings of the Royal Society, Series B, 154, 21 Paton, W. D. M. (1967). Annals of the New York Academy of Sciences, 139, 632.

Pearson, R. S. B. (1963). In Salicylates, ed. A. St. J. Dixon, B. K. Martin, M. J. H. Smith, and P. H. N. Wood, p. 170. London, Churchill.

Von Rechenberg, H. K. (1962). Phenylbutzaone, p. 147. London, Arnold. Samter, M., and Beers, R. (1967). Fournal of Allergy, 40, 281.

Samter, M., and Beers, R. (1968). Annals of Internal Medicine, 68, 975.

Van Leeuwen, W. S. (1924). Fournal of Pharmacology and Experimental Therapeutics, 24,25 .

Vanselow, N. A., and Smith', J. R. (1967). Annals of Internal Medicine, 66, 568. 